This is an electronic reprint of the original article. This reprint may differ from the original in pagination and typographic detail.

Author(s): Salonen, Jouni; Luhta, Pirkko-Liisa; Moilanen, Eero; Oulasvirta, Panu; Turunen, Jarno; Taskinen, Jouni

Title: $\quad$ Atlantic salmon (Salmo salar) and brown trout (Salmo trutta) differ in their suitability as hosts for the endangered freshwater pearl mussel (Margaritifera margaritifera) in northern Fennoscandian rivers

Year: $\quad 2017$

Version:

Please cite the original version:

Salonen, J., Luhta, P.-L., Moilanen, E., Oulasvirta, P., Turunen, J., \& Taskinen, J. (2017). Atlantic salmon (Salmo salar) and brown trout (Salmo trutta) differ in their suitability as hosts for the endangered freshwater pearl mussel (Margaritifera margaritifera) in northern Fennoscandian rivers. Freshwater Biology, 62(8), 13461358. https://doi.org/10.1111/fwb.12947

All material supplied via JYX is protected by copyright and other intellectual property rights, and duplication or sale of all or part of any of the repository collections is not permitted, except that material may be duplicated by you for your research use or educational purposes in electronic or print form. You must obtain permission for any other use. Electronic or print copies may not be offered, whether for sale or otherwise to anyone who is not an authorised user. 


\section{Atlantic salmon (Salmo salar) and brown trout (Salmo trutta) differ in their suitability as a host for the endangered freshwater pearl mussel (Margaritifera margaritifera) in northern Fennoscandian rivers}

Jouni K. Salonen ${ }^{1 *}$, Pirkko-Liisa Luhta ${ }^{2}$, Eero Moilanen ${ }^{2}$, Panu Oulasvirta ${ }^{3}$, Jarno Turunen $^{4,5}$ and Jouni Taskinen ${ }^{1}$

${ }^{1}$ Department of Biological and Environmental Science, P.O. Box 35, FI-40014 University of Jyväskylä, Finland

${ }^{2}$ Natural Heritage Services Ostrabothnia, Karhukunnaantie 2, FI-93100 Pudasjärvi, Finland

${ }^{3}$ Alleco Ltd., Veneentekijäntie 4, FI-00210 Helsinki, Finland

${ }^{4}$ Department of Ecology, P.O. Box 3000, FI-90014 University of Oulu, Finland ${ }^{5}$ Finnish Environment Institute, Freshwater Centre, P.O. Box 413, FI-90014 Oulu, Finland

* Correspondence to: Department of Biological and Environmental Science, P.O. Box 35, FI-40014 University of Jyväskylä, Finland. Tel.: +358 40805 3874. E-mail: jouni.k.salonen@jyu.fi

\section{Running Head}

Host specificity of the freshwater pearl mussel

\section{Keywords}

affiliate species; glochidia; host-parasite; river damming; salmonid stocking 


\section{Summary}

1. European populations of the freshwater pearl mussel (FPM, Margaritifera margaritifera) have widely collapsed, and despite many types of conservation actions the number of successful restoration trials has remained limited. The goal of this study was to find new aspects for the conservation by investigating whether there are population-specific differences in suitability of Atlantic salmon (Salmo salar) and brown trout (S. trutta) as the hosts for the parasitic glochidium larvae of FPM, depending probably on the historical occurrence of these salmonid species in FPM habitats.

2. We studied the potential host specificity both in the field and in laboratory by exposing salmonid fish to FPM glochidia originating from nine populations of different types of streams and rivers within three different large river basins of northern Fennoscandia.

3. The exposures showed remarkable population-specific differences in the host species suitability. In large main channels, previously colonized by Atlantic salmon but most now dammed for hydropower production, the occurrence of FPM glochidia was always highest in salmon. Moreover, the glochidia in salmon were often larger than the conspecifics in brown trout. Conversely, in small tributaries with no salmon history, brown trout was generally the best, or the only suitable, host for FPM.

4. Especially the adaptation of certain FPM populations exclusively on salmon is a considerable finding, which offers - together with the hydropower dam construction and the salmonid fish stocking practices often favouring brown trout - an additional explanation for the collapse of FPM populations living in former Atlantic salmon rivers.

5. Furthermore, this study illustrates the indirect but substantial effects that river damming and changes in fish communities may induce, and emphasize the need to investigate the most suitable host species for each FPM population as the basis for management and conservation actions. 


\section{Introduction}

Due to the unsustainable use of natural resources of the Earth in the present Anthropocene period (Pimm et al., 1995; Crutzen, 2002), a large proportion of global biodiversity has faced extinction or is at risk of extinction via climate change, habitat degradation, overharvesting and introduction of invasive species (Sala et al., 2000; Thomas et al., 2004). One particularly challenging aspect in biodiversity conservation is that the loss of certain species from an ecosystem can have cascading effects on other species due to their large role on ecosystem processes or the interdependence of species on each other (Paine, 1995; Dunn et al., 2009). For example, among coevolved, highly specialized associated species such as partners in many plant-pollinator and hostparasite relationships the extinction of one component of the relationship often leads to the extinction of another (Dunn, 2005; Dunn et al., 2009).

An additional complication for conservation of a species having close interaction with another species is the potential variation in the pattern of specificity of these betweenspecies relationships on a local scale, e.g. populations of a parasite species may have evolutionarily adapted to use different hosts in different regions (Thompson, 2005; Poulin, 2007). One such system is the host-parasite relationship between salmonid fishes and their highly specialized bivalvian parasite, the freshwater pearl mussel (Margaritifera margaritifera, Margaritiferidae, hereafter FPM). This mollusc, which has a complex life cycle involving a parasitic stage of eight to 12 months in the gills of salmonid fish (Young \& Williams, 1984; Geist, Porkka \& Kuehn, 2006; Geist, 2010), lives in oligotrophic rivers and streams on both sides of the Atlantic Ocean (Bauer, 1986; Young, Cosgrove \& Hastie, 2001; Lopes-Lima et al., 2016). FPM was formerly abundant but declined substantially in the $20^{\text {th }}$ century throughout its distribution area (Bauer, 1986; Beasley, Roberts \& Mackie, 1998; Cosgrove et al., 2000; Lopes-Lima et $a l ., 2016)$ so that it is now listed as a critically endangered species in Europe (Cuttelod, Seddon \& Neubert, 2011).

In Europe, the confirmed hosts of FPM are Atlantic salmon (Salmo salar, Salmonidae) and brown trout (Salmo trutta, Salmonidae), which have generally thought to be equally 
suitable hosts (e.g. Young \& Williams, 1984; Bauer, 1987b, 1987c). However, the role of these species for conservation of FPM may be more complicated than previously acknowledged, because some FPM populations have recently been reported to exclusively parasitize either salmon or brown trout (Hastie \& Young, 2001; Karlsson, Larsen \& Hindar, 2014; Österling \& Wengström, 2015). In general, the theory of hostparasite coevolution suggests that parasites are usually adapted to the most frequently encountered host genotype of the habitat (Thompson, 1994; Dybdahl \& Storfer, 2003; Greischar \& Koskella, 2007). According to that theory, FPM living in a salmondominated large river channel would become genetically adapted to use Atlantic salmon as the primary host, whereas adaptation to use brown trout as the host may be more common in smaller tributary streams often colonized by brown trout as the only salmonid (e.g. Baglinière, Prévost \& Maisse, 1994; Johansen, Elliott \& Klemetsen, 2005). Thus, if this phenomenon is widespread throughout the distribution area of FPM, the changes in fish communities, e.g. loss of the primary salmonid host even though the other one but less suitable salmonid remained, could represent an additional threat to FPM.

Indeed, there are facts which indicate that the lack of the most suitable host species may even be one of the most important factors behind the collapse of FPM in certain circumstances. Many anthropogenic environmental disturbances, such as pollution and eutrophication, have evidently been disastrous for FPM (Bauer, 1983, 1986, 1988; Beasley et al., 1998; Beasley \& Roberts, 1999; Geist, 2010; Gosselin, 2015). However, many of the remaining populations in undisturbed, or successfully restored, habitats still are suffering from the lack of juvenile mussels (see Lopes-Lima et al., 2016). This indicates more populations becoming extinct in the near future (Bauer, 1983, 1986; Beasley et al., 1998; Geist et al., 2006; Cosgrove et al., 2000; Geist, 2010), but also that there may be unidentified, reproduction-related factors behind the decline. Another fact is that many large European river systems were harnessed for hydroelectric production in the 1900s, causing fragmentation in river connectivity and preventing the natural migration of anadromous fish, including Atlantic salmon, to these rivers (Parrish et al., 1998; Bardonnet \& Baglinière, 2000; Kallio-Nyberg et al., 2010; Erkinaro et al., 2011; Gosselin, 2015). Moreover, the salmonid species used for the compensatory salmonid 
stocking are not generally required to be the same as the lost species (Hiltunen, 2010; Erkinaro et al., 2011; Marttila et al., 2014), and in many rivers the loss of Atlantic salmon has been compensated by hatchery-reared brown trout (Luhta \& Moilanen, 2006; Hiltunen, 2010). Furthermore, building of more hydroelectric dams promoted as a renewable, green energy source may be possible in the future (see Erkinaro et al., 2011 and references therein). Thus, the potential host suitability differences between FPM populations need urgent investigation to take it into account both in the future management plans and fish stockings into FPM rivers especially in northern Fennoscandia, where the genetically most diverse FPM populations occur (Geist \& Kuehn, 2008; Geist et al., 2010).

The aim of this study was to investigate whether the (historical) occurrence of salmonid species generally defines the most suitable host species for each population. The hypothesis was that Atlantic salmon would be the most preferred host for FPM living in (formerly) salmon-dominated large rivers, while brown trout would be more suitable host in small FPM streams only ever inhabited by brown trout. Thus, salmon and brown trout were experimentally exposed to FPM glochidia originating from the both types of rivers. In total, nine different FPM populations from three large Finnish/Russian river basins were used in the experiments conducted mainly in rivers utilizing mussels' natural glochidium shedding. However, to follow glochidia development and since placing alive fish from non-original populations to the rivers was not always allowed, experiments were also conducted in laboratory tanks with controlled glochidia exposures.

\section{Methods}

Field work was conducted in tributaries of the River Iijoki catchment $\left(14200 \mathrm{~km}^{2}\right)$, and in main channels of the rivers Livojoki (Iijoki catchment), Simojoki (catchment of 3160 $\mathrm{km}^{2}$ ), and Luttojoki (Tuloma catchment of $21500 \mathrm{~km}^{2}$ ) in Finland, northern Europe (Figure 1). The rivers Livojoki and Luttojoki were both used by Atlantic salmon as a spawning and nursery area until the mid-1900s, when the catchments were dammed for electricity production (Karppinen et al., 2002; Erkinaro et al., 2011). The undammed 
River Simojoki still harbours a natural Atlantic salmon population. The rest FPM habitats of the study (Ala-Haapuanoja, Jukuanoja, Koivuoja, Lohijoki, Porraslammenoja, and Portinjoki) are small streams in the Iijoki catchment (Figure 1) and have been assessed to be inhabited only by brown trout (resident or anadromous) and not by Atlantic salmon even before construction of the dams. These assessments are based on local, unpublished knowledge and documents - salmon fishing was an important occupation in the area in the past and thus the former migratory reaches of salmon are well known. The small size of the channels $\left(1^{\text {st }}\right.$ and $2^{\text {nd }}$ order headwater streams; see Strahler, 1952) and the habitat preferences of these salmonid species (e.g. Baglinière et al., 1994; Erkinaro, 1995; Johansen et al., 2005) also support the assessments. The main characteristics of each of the study rivers are presented in Table S1 in Supporting Information. To protect FPM, exact coordinates for the mussel habitats are not presented, but are available from the authors.

The strains of the original Iijoki salmonids, Atlantic salmon and anadromous brown trout, have been maintained in hatcheries during the decades after hydropower dam construction. Fish from these strains were obtained from fish farms of the Natural Resources Institute Finland or Kalankasvatus Vääräniemi. Brown trout from certain land-locked strains (see below) - widely used in fish stocking to compensate the loss of anadromous salmonids in the study areas (Luhta \& Moilanen, 2006; Hiltunen, 2010) and Tornionjoki salmon were also obtained from these farms. Simojoki salmon and resident brown trout were electrofished (which is harmless to FPM; Hastie \& Boon, 2001) from the study rivers before the experiments.

The licences to handle FPM, expose fish to FPM, and to sacrifice limited number of wild salmonids were acquired from the regional Centres for Economic Development, Transport and the Environment and from the Animal Experiment Board of Finland.

\section{Cage experiments}

The cage experiments included placing individuals of Atlantic salmon and brown trout in cages into FPM rivers shortly before the annual glochidium shedding in 2011-2013. 
Circular cages of height $250 \mathrm{~mm}$, diameter $490 \mathrm{~mm}$ and mesh $5.7 \mathrm{~mm}$ were placed close to the FPM habitats. The fish species and strains were randomly allocated into two to four replicate cages with 20-35 fish per cage per river; exceptions occurred in the streams Porraslammenoja (only three individuals of resident brown trout captured) and Koivuoja (no resident fish caught). The study rivers with caged fish, numbers of replicates per fish strain and total numbers of fish in the replicates in each experiment are presented in Table 1.

To allow enough time for the FPM exposure but also for the detachment of glochidia from unsuitable hosts (Bauer \& Vogel, 1987; Österling \& Larsen, 2013), the experiments were concluded and the fish examined more than one month after the beginning of the caging (see details in Table 1). An exception was the year 2011 when only about one third of fish in each group was examined immediately after the caging, while the rest were moved alive to laboratory and examined there later at different time points. Moreover, in 2011 neither the age nor thus the size of fish was equal, unlike in 2012-2013, when only 0+ (i.e. hatched in the same year) fish were used. Maximum total length of fish (measured after the caging) was $82 \mathrm{~mm}$ in 2012 and $86 \mathrm{~mm}$ in 2013. Thus, only fish of length less than $85 \mathrm{~mm}$ were used in the 2011 analysis, as it is safe to assume that the age of these fish was $0+$. The gill areas of fish were then comparable to each other and the numbers of glochidia did not need to be standardized to fish size (see Taeubert et al., 2010). Moreover, possible acquired immunity (Hastie \& Young, 2001; Chowdhury et al., 2017) could not confuse the interpretation of the results when no fish had been in contact with FPM earlier. The 0+ salmonids are also widely suggested to be the most suitable hosts for FPM (Young \& Williams, 1984; Bauer, 1987b; Hastie \& Young, 2001; Österling, 2015). 
For examination, fish were killed, after which total length and fresh mass were measured. The gills were then removed and pressed between two glass plates, and the number of FPM glochidia on each gill was counted microscopically. In 2012 and 2013, the length (longest diameter of round or slightly oval larva) of 10 randomly picked glochidia was also measured per each fish.

\section{Laboratory experiments}

Fish were artificially exposed to FPM glochidia in laboratory tanks at Konnevesi Research Station (University of Jyväskylä) in 2011-2013. The water to the laboratory came from the nearby Lake Konnevesi, belonging to a catchment which harbours no FPM. The origins of FPM, the salmonid strains used, numbers of replicate tanks per strain and total numbers of fish (fed with commercial feed once per day) in the replicates in each experiment are presented in Table 2.

FPM glochidia in the experiments originated in each year from a different river and were collected in early autumn (Table 2), shortly before the expected glochidia shedding season. A common non-destructive method (see e.g. Young \& Williams, 1984; Bauer, 1987a) was used: several mussels were transferred to buckets filled with water and probably due to stress the gravid mussels soon released their glochidia into the water. The glochidial suspension with additional water and aerators was then transported to the laboratory. In 2011, a high mortality (> 95\%) of glochidia in suspension was detected and the concentration was only $100000 \pm 8000$ (S.E.) live larvae per litre. In 2012 and 2013, there was only minor $(<5 \%)$ mortality and the concentrations were $590000 \pm 180000$ larvae $\mathrm{L}^{-1}$ and $1200000 \pm 170000$ larvae $\mathrm{L}^{-1}$, respectively.

For 60 min exposure, water flow in each $163 \mathrm{~L}$ fish tank was turned off, volumes of water were decreased to $70 \mathrm{~L}$, and extra aeration was provided. Then, $2 \mathrm{~L}$ (2011), $1 \mathrm{~L}$ (2012), or 0.5 L (2013) of FPM suspension was added to each tank. The success of the procedure was confirmed a day later by examining some fish for FPM glochidia. Fish 
were subsequently examined (using the above-mentioned methods) at different time points in the first two experiments, while in the last experiment all the fish were sacrificed at the same time two months after the exposure (Table 2).

Some mortality and escape of fish was observed during the studies, but the only considerable incident happened in the last laboratory experiment. There, all individuals of Atlantic salmon (0+) escaped within a few weeks of the start of the experiment, probably through a too large mesh in the covers of the tanks. Thus, individuals of $1+$ aged Atlantic salmon (meant for another experiment, but obtained, maintained and exposed to FPM in identical manner as the original 0+ salmon) were used as comparison fish for the 0+ brown trout in that experiment. Moreover, in the same experiment the fin clip marking of two brown trout strains failed, making it impossible to separate the strains at the examination day. Thus, brown trout data were pooled and compared to salmon as a whole (Table 2).

\section{Statistics}

The suitability of the species as a host for certain FPM populations was analysed by comparing both the prevalence (percentage of fish carrying FPM glochidia, \%), and the abundance (median number of glochidia per fish) of FPM infection between species. Furthermore, glochidia length was compared between the hosts in 2012-2013 experiments. Between-species differences in prevalence were analysed using $\chi^{2}$ test (or Fisher's exact test if the criteria for the use of $\chi^{2}$ test were not met), in abundance using Mann-Whitney $U$ test, and in glochidia length using ANOVA (or Mann-Whitney $U$ test if the criteria for the use of parametric tests were not met). In the latter case, the mean glochidia length for a fish group was estimated by first estimating the mean glochidia length in each fish, and then calculating the total mean from these individual means. Spearman rank correlation to test the association between time point and mean number of glochidia, and between time point and mean length of glochidia, was used in the second laboratory experiment. SPSS version 22.0.01. (IBM Corporation, NY, USA) was used for all statistical analyses. All the $p$-values in multiple comparisons were 
Bonferroni corrected, and a risk level of $p<0.05$ was considered statistically significant and $0.05 \leq p<0.1$ statistically marginally significant.

In the last laboratory experiment with age and thus size difference between the fish groups, each number of glochidia was standardized by dividing the number by the weight of the host, i.e. the method recommended by Taeubert et al. (2010). An alternative standardization method (number of larvae divided by length of fish) presented by Tauebert et al. (2010) was also tested. The mean total lengths for each fish group in each experiment are given in Table S2 in Supporting Information.

Before the comparisons between species, potential differences in prevalence and abundance between the replicate tanks and cages, and between different time points, within a fish group were analysed using the statistical tests mentioned above. The only significant differences were found between the time points in the laboratory experiment 2012-2013. Thus, the data from that experiment were analysed separately for each of the four time points (two weeks, three weeks, three months and six and a half months after the infection day), while in every other experiment data from the replicates and time points were pooled for the further analyses.

To obtain a comprehensive assessment of the possible host specificity, the results were also finally combined over the brown trout streams and over the salmon rivers using Fisher's combined probability test. For this, the different strains of species were first combined in each experiment, after which the species were compared to each other with the methods described above. Thus, only one $p$-value (salmon vs brown trout) was obtained in every experiment for the 1-tailed hypothesis that the most suitable FPM host in small streams is brown trout, and in large rivers salmon. These $p$-values from independent tests were then combined with the Fisher's method. The prevalence, the abundance and the glochidial length were all analysed using this method.

\section{Results}

\section{Brown trout streams}


There were no differences in host suitability between brown trout and Atlantic salmon for FPM population originating from the Lohijoki stream (Figure 2a, Table 3a). However, in four out of tested six brown trout streams (Portinjoki, Ala-Haapuanoja, Porraslammenoja, Jukuanoja) brown trout was better FPM host than Atlantic salmon in terms of prevalence of infection, median abundance of infection and/or mean length of glochidia. In the Portinjoki stream (Figure 2b) the abundance was significantly higher in two of three tested brown trout strains than in salmon (Table 3a). In the Ala-Haapuanoja stream (Figure 2c) the abundance was significantly higher in each of the three brown trout strains than in salmon (Table 3a). In the Porraslammenoja stream (Figure 2d), both the prevalence and the abundance were significantly higher in two of three brown trout strains than in salmon, and the abundance was also marginally higher in the third brown trout strain (Table 3a). Moreover in the river Porraslammenoja, the length of glochidia (Table 4) was smallest in salmon, the difference to one brown trout strain being marginally significant (Table 3a).

In the laboratory experiment using FPM from the Jukuanoja stream (Figure 3), both the prevalence and the abundance were significantly higher in brown trout than in salmon at every four time point from September to March (Table 3a). FPM glochidia were also significantly greater in brown trout than in salmon at the second time point three weeks after the attachment (Table 3a, Table 5). Furthermore, no glochidia were found on salmon at any later time points (Figure 3), while in brown trout glochidia remained to the end of the experiment with no significant reduction in the mean number $(p=0.400)$. The length of FPM glochidia in brown trout increased significantly $(p<0.001)$ throughout the experiment (Table 5).

As an exception to the general trend, Atlantic salmon was found to be more suitable host for Koivuoja FPM population. In the cage experiment (Figure 4a) the abundance was marginally significantly higher in salmon than in brown trout (Table 3 ). In the laboratory experiment (Figure 4b), both the prevalence and the abundance were significantly higher in salmon than in brown trout (Table 3a). 
Combined analysis of these results from different brown trout streams using the Fisher's method showed the prevalence and the abundance of FPM infection, as well as the length of glochidia, to be significantly higher in brown trout than in salmon $(p<0.001$ in each instance).

\section{Salmon rivers}

In all five experiments among three different large salmon rivers, Atlantic salmon was better FPM host than brown trout in terms of prevalence of infection, median abundance of infection and/or mean length of glochidia. In the River Livojoki in 2011 (Figure 5a), 2012 (Figure 5b) and 2013 (Figure 5c) the prevalence was significantly higher in salmon than in brown trout in eight out of nine comparison cases, the abundance in seven out of nine cases, and the length of glochidia in four out of six cases (Table $3 b$ ). Also in the River Simojoki (Figure 5d), both the prevalence and the abundance were significantly higher in all salmon strains than in brown trout, while there were no significant differences in length of glochidia between the salmon strains and brown trout (Table 3b).

As the field experiments, also the laboratory experiment using FPM from the River Luttojoki (Figure 6) revealed both the prevalence and the fish weight corrected abundance being significantly higher in salmon than in brown trout (Table $3 b$ ). The difference in non-corrected, actual numbers of glochidia was also very high: mean \pm S.E. was $1037 \pm 121$ per salmon and $99 \pm 13$ per brown trout, and the alternative standardization method of number of larvae divided by fish length did not alter the result $(p<0.001)$. FPM glochidia were also significantly larger in salmon than in brown trout (Table 3b, Table 5).

Overall, brown trout was not better FPM host than salmon in any of the comparison cases in the salmon rivers. Not surprisingly, combined analysis of the results from different salmon rivers using the Fisher's method showed the prevalence and the abundance of FPM infection, as well as the length of glochidia, to be significantly higher in salmon than in brown trout ( $p<0.001$ in each instance). 


\section{Discussion}

Our results confirm that there are substantial differences in suitability of Atlantic salmon and brown trout as hosts for certain freshwater pearl mussel (FPM, $M$. margaritifera) populations in northern Fennoscandian rivers. Thus, given that FPM glochidia can metamorphose to juvenile mussel only in these salmonids (Bauer, 1987b, 1987c; Beasley \& Roberts, 1999; Salonen, Marjomäki \& Taskinen, 2016) but only in one or the other one in certain river, FPM can be regarded as highly host-specific parasite, populations of which seem to be adapted to parasitize only the (historically) most prevalent salmonid species of their habitat. In large rivers, where Atlantic salmon migrate (or migrated before the rivers were dammed) for spawning, the best host was always the salmon. In contrast, in small tributaries naturally inhabited by brown trout, the brown trout usually was the most suitable host - or even the only suitable as all the glochidia originating from Jukuanoja FPM prematurely dropped off from salmon. However, FPM population in the small Koivuoja stream seems to prefer salmon rather than brown trout as host, and there also was a population that showed no suitability difference between the salmonids hosts. These results have to be taken into account in management actions to restore FPM habitats, which often include stocking of salmonids hosts (Bauer, 1988; Buddensiek, 1995; Geist et al., 2006).

To our knowledge, the potential specialization of certain FPM populations to use exclusively either salmon or brown trout as their host was first suggested by Beasley \& Roberts (1999), who caught both species from two Irish rivers, but found only brown trout to be parasitized by FPM. Subsequently, similar results have been reported from Scotland (Hastie \& Young, 2001) Norway (Karlsson et al., 2014), and Sweden (Österling \& Wengström, 2015). Of these studies, Hastie \& Young (2001) obtained their results from a sample of naturally exposed wild fish, and suggested the reason for higher infectivity of FPM in salmon was the different habitat preferences of the salmonid species. In fact, our results show that the use of different habitats is not a general explanation for the host suitability differences. In their investigations of two FPM rivers, Österling \& Wengström (2015) found that brown trout was the only 
suitable FPM host, even though Atlantic salmon was also present. As they also stated, that no salmon-dependent FPM population has been found in Sweden at all, our results with the salmon-specific FPM populations in the large rivers Livojoki and Simojoki are unique findings in the Baltic Sea area. However, Ieshko et al. (2016) recently found land-locked Lake Ladoga (Baltic Sea drainage) salmon to be a natural host for FPM in a Russian river, but did not find any brown trout for host comparison. In Norway, FPM populations potentially parasitizing only either brown trout or salmon have been found in field surveys throughout the country (Karlsson et al., 2014). Overall, according to our study and these previous results, the host salmonid specificity of FPM is a common phenomenon that likely occurs also elsewhere. Thus, together with changes in salmonid communities in the distribution area of FPM, the local variation in host specificity patterns can be an indirect but major factor contributing to the widespread collapse of this bivalve.

Generally, if a FPM population has the evolved ability to parasitize both salmonid species, the absence of one species will not prevent the recruitment of the population if the other host species is still present. Furthermore, the ability to use salmon as a host may help dispersal and increase the recruitment potential of FPM, as salmon is considered more mobile than brown trout (Klemetsen et al., 2003; Johansen et al., 2005). In contrast, strict specialization to use only the local, resident brown trout, which usually remain continuously in the same small area (Knouft \& Spotila, 2002), as the host is likely to limit the dispersal of FPM and thus e.g. increase inbreeding risk. Hostspecific populations may also be the most vulnerable to local changes in fish communities. Karlsson et al. (2014) also argued that the (Norwegian) FPM populations that use only brown trout as their host will be more vulnerable to extinction in future, due to their generally low genetic diversity.

However, there are numerous river systems where the present situation of salmonspecific FPM populations might be worse than that of populations adapted to brown trout, due to the intensive construction of hydroelectric power plants that lack fishways and thus prevent the migration of salmon (Karppinen et al., 2002; Erkinaro et al., 2011; Marttila et al., 2014). For example, the River Livojoki and its FPM population have 
been isolated from anadromous salmon for more than 50 years (Hiltunen, 2010; Erkinaro et al., 2011; Marttila et al., 2014). Furthermore, the compulsory salmonid stockings above the dams have been generally conducted by releasing farmed brown trout, but no salmon, to the area (Luhta \& Moilanen, 2006; Hiltunen, 2010). Simultaneously, a substantial collapse in the number of FPM individuals and especially in the occurrence of juvenile mussels in the river has been detected (Valovirta, 1990, 1993). Our results clearly show that the most suitable, or probably in the long run the only suitable, host for the Livojoki FPM population is Atlantic salmon. Therefore, the priority for conservation of FPM population in the River Livojoki, as in any dammed river previously colonized by both salmon and FPM, must be to restore the indigenous salmonid, Atlantic salmon, to the river. Thus, the species used in the salmonid stockings in these rivers should always be the salmon, but for restoring a sustainable recruiting Atlantic salmon population it is necessary to allow the free migration of both spawners (upstream) and smolts (downstream). At least, existing dams need efficient fishways and operation modes to ensure the migrations.

The FPM population in the River Luttojoki in the northernmost Finland was also confirmed to be highly salmon-dependent. The main channel of the catchment was harnessed for hydroelectric production in the mid-1900's, thus preventing migration of Atlantic salmon (Karppinen et al., 2002; Oulasvirta, 2011). Furthermore, there have been only sparse and sporadic salmonid stockings in the catchment and FPM recruitment in the River Luttojoki has also declined (Oulasvirta, 2011). Thus, unless actions to restore Atlantic salmon to the river are taken, the Luttojoki FPM population will inexorably face extinction in the near future.

The laboratory experiment with Luttojoki FPM used unequally aged fish: 0+ brown trout and 1+ salmon. However, obviously neither prevalence nor glochidia length (both significantly higher in salmon) can be affected by the size or age of the identically exposed fish with no earlier contact to FPM. The initial abundance of FPM glochidia may increase with fish size due to increased gill area (Hastie \& Young, 2001; Ieshko et $a l ., 2009)$, but this effect was ruled out by scaling the glochidia abundance to fish size as recommended by Taeubert et al. (2010). Furthermore, 0+ fish (brown trout in this 
instance) should generally be better hosts than older individuals even without the potential immunity acquired in earlier FPM exposures (Young \& Williams, 1984; Bauer, 1987b; Österling \& Wengström, 2015). Thus, despite the size and age difference of the species in the experiment, salmon can be without doubt judged as the best host fish species for Luttojoki FPM population.

Despite the observed host specificity, the FPM populations or individuals in small brown trout streams may be more flexible in terms of suitable host species than the populations in large salmon rivers; brown trout was a significantly better host in most of the small streams, but in some of these streams all the salmon individuals also were parasitized by FPM. Furthermore, in the brown trout stream Koivuoja, both prevalence and abundance were higher in salmon than in brown trout whose mean abundance was less than 100 glochidia per fish in both the cage and the laboratory experiments. However, in earlier surveys conducted in Koivuoja, wild brown trout samples with prevalence of $100 \%$ and mean abundance more than 800 glochidia were caught (see Salonen \& Taskinen, 2017). Unfortunately, this time no resident Koivuoja brown trout individuals were caught and caged. In any case, according to local knowledge and the small size of the Koivuoja stream, as well as the more than $10 \mathrm{~km}$ distance from the Iijoki main channel to the caging location and with a lake en route, previous spawning migration by Atlantic salmon to the Koivuoja stream is unlikely. However, it has been found that juvenile salmon can migrate to feed in small headwater streams where the adult fish do not spawn (Erkinaro, 1995; Erkinaro \& Erkinaro, 1998). Erkinaro (1995) also found that a few young salmon may even overwinter in the small streams to which they migrated in summer. Thus, if this kind of behaviour of salmon had also occurred in the Iijoki area before the hydropower construction, some adaptation of FPM to parasitize salmon in addition to brown trout may have occurred in the small streams, providing a possible explanation for our findings in the case of Koivuoja stream. It is notable, that two different methods (field and laboratory) were used to infect fish with Koivuoja FPM and the results were identical, indicating consistency of the methods.

Techniques for culturing FPM in laboratory are widely in use (e.g. Buddensiek, 1995; Gum, Lange \& Geist, 2011). Our results show that for the best success of such 
programs it is vital to investigate the potential host specificity of the population from which the parental mussels originate. Moreover, the availability of the suitable host species in the rivers where the juvenile mussels will be placed has to be confirmed. To sum up, our study demonstrates the evolved population-level host specificity differences in different FPM populations depending on the historical occurrence of the host salmonid species. Most importantly, the results indicate that in certain rivers the physical restoration of FPM habitats do not alone rescue the remaining mussel populations from extinction if the suitable host species is lacking and not restored. Extinction of FPM may have severe effects on the whole biodiversity due to the filtering activity of mussels (Howard \& Cuffey, 2006; Vaughn, Nichols \& Spooner, 2008) which benefits many organisms in the river ecosystem (Hastie \& Cosgrove, 2001; Geist, 2010). However, considering the high fecundity and the extremely long life span of FPM (Helama \& Valovirta, 2007), in addition to the fact that Atlantic salmon has not lost its instinct to migrate to their old spawning rivers despite the migration having been prevented for many generations (e.g. Karppinen et al., 2002; Orell et al., 2011), immediate action still has the potential to enable mussel populations to recover especially in the dammed salmon rivers. Furthermore, the observed host specificity phenomenon is unlikely to be restricted only to FPM, and thus the population level differences in host specificity of other endangered bivalves should be more widely investigated for more effective conservation. Present results also demonstrates the lessunderstood but dramatic cascading effects of river fragmentation and the consequent change in river ecosystem on an affiliate species which is directly dependent on presence of another species (see Dunn, 2005; Dunn et al., 2009). 


\section{Acknowledgements}

We would like to thank Olli Nousiainen, Tapani Säkkinen, Felix Luukkanen and Motiur Chowdhury for their help with laborious field and laboratory work. Personnel of the Konnevesi research station are also acknowledged. Comments and suggestions by Timo J. Marjomäki, Jukka Syrjänen and Santtu Välilä helped us to strengthen the manuscript, and Roger Jones, Jocelyn Mah Choo and Stuart Lambie kindly checked the English language. We also are grateful to the Maj and Tor Nessling Foundation, the Olvi Foundation, the Finnish Foundation for Nature Conservation, the EU Interreg IV A Nord Programme and the Doctoral Programme in Biological and Environmental Science of the University of Jyväskylä for financial support. 


\section{References}

Baglinière J.-L., Prévost E. \& Maisse G. (1994) Comparison of population dynamics of Atlantic salmon (Salmo salar) and brown trout (Salmo trutta) in a small tributary of the River Scorff (Brittany, France). Ecology of Freshwater Fish, 3, 25-34.

Bardonnet A. \& Baglinière J.-L. (2000) Freshwater habitat of Atlantic salmon (Salmo salar). Canadian Journal of Fisheries and Aquatic Sciences, 57, 487-506.

Bauer G. (1983) Age structure, age specific mortality rates and population trend of the freshwater pearl mussel (Margaritifera margaritifera) in North Bavaria. Archiv für Hydrobiologie, 98, 523-532.

Bauer G. (1986) The status of the freshwater pearl mussel Margaritifera margaritifera L. in the south of its European range. Biological Conservation, 38, 1-9.

Bauer G. (1987a) Reproductive strategy of the freshwater pearl mussel Margaritifera margaritifera. Journal of Animal Ecology, 56, 691-704.

Bauer G. (1987b) The parasitic stage of the freshwater pearl mussel (Margaritifera margaritifera L.) II. Susceptibility of brown trout. Archiv für Hydrobiologie, Supplements, 76, 403-412.

Bauer G. (1987c) The parasitic stage of the freshwater pearl mussel (Margaritifera margaritifera L.) III. Host relationships. Archiv für Hydrobiologie, Supplements, 76, 413-423.

Bauer G. (1988) Threats to the freshwater pearl mussel Margaritifera margaritifera $\mathrm{L}$. in Central Europe. Biological Conservation, 45, 239-253.

Bauer G. \& Vogel C. (1987) The parasitic stage of the freshwater pearl mussel (Margaritifera margaritifera L.) I. Host response to glochidiosis. Archiv für Hydrobiologie, Supplements, 76, 393-402.

Beasley C.R. \& Roberts D. (1999) Towards a strategy for the conservation of the freshwater pearl mussel Margaritifera margaritifera in County Donegal, Ireland. Biological Conservation, 89, 275-284.

Beasley C.R., Roberts D. \& Mackie T.G. (1998) Does the freshwater pearl mussel, Margaritifera margaritifera L., face extinction in Northern Ireland? Aquatic Conservation: Marine and Freshwater Ecosystems, 8, 265-272. 
Buddensiek V. (1995) The culture of juvenile freshwater pearl mussels Margaritifera margaritifera L. in cages: a contribution to conservation programmes and the knowledge of habitat requirements. Biological Conservation, 74, 33-40.

Chowdhury M.M.R., Salonen J.K., Marjomäki T.J. \& Taskinen J. (2017) Interaction between the endangered freshwater pearl mussel Margaritifera margaritifera, the duck mussel Anodonta anatina and the fish host (Salmo): acquired and cross-immunity. Hydrobiologia, DOI: 10.1007/s10750-017-3114-6.

Cosgrove P.J., Young M.R., Hastie L.C., Gaywood M. \& Boon P.J. (2000) The status of the freshwater pearl mussel Margaritifera margaritifera Linn. in Scotland. Aquatic Conservation: Marine and Freshwater Ecosystems, 10, 197-208.

Crutzen P.J. (2002) Geology of mankind. Nature, 415, 23.

Cuttelod A., Seddon M. \& Neubert E. (2011) European red list of non-marine molluscs. Luxembourg: Publications Office of the European Union.

Dunn R.R. (2005) Modern insect extinctions, the neglected majority. Conservation Biology, 19, 1030-1036.

Dunn R.R., Harris N.C., Colwell R.K., Koh L.P. \& Sodhi N.S. (2009) The sixth mass coextinction: are most endangered species parasites and mutualists? Proceedings of the Royal Society of London B, 276, 3037-3045.

Dybdahl M.F. \& Storfer A. (2003) Parasite local adaptation: Red Queen versus Suicide King. Trends in Ecology and Evolution, 18, 523-530.

Erkinaro J. (1995) The age structure and distribution of Atlantic salmon parr, Salmo salar L., in small tributaries and main stems of the subarctic River Teno, northern Finland. Ecology of Freshwater Fish, 4, 53-61.

Erkinaro H. \& Erkinaro J. (1998) Feeding of Atlantic salmon, Salmo salar L., parr in the subarctic River Teno and three tributaries in northernmost Finland. Ecology of Freshwater Fish, 7, 13-24.

Erkinaro J., Laine A., Mäki-Petäys A., Karjalainen T.P., Laajala E., Hirvonen A. et al. (2011) Restoring migratory salmonid populations in regulated rivers in the northernmost Baltic Sea area, Northern Finland - biological, technical and social challenges. Journal of Applied Ichthyology, 27, 45-52. 
Geist J. (2010) Strategies for the conservation of endangered freshwater pearl mussels (Margaritifera margaritifera L.): a synthesis of conservation genetics and ecology. Hydrobiologia, 644, 69-88.

Geist J. \& Kuehn R. (2008) Host-parasite interactions in oligotrophic stream ecosystems: the roles of life-history strategy and ecological niche. Molecular Ecology, 17, 997-1008.

Geist J., Porkka M. \& Kuehn R. (2006) The status of host fish populations and fish species richness in European freshwater pearl mussel (Margaritifera margaritifera) streams. Aquatic Conservation: Marine and Freshwater Ecosystems, 16, 251-266.

Geist J., Söderberg H., Karlberg A. \& Kuehn R. (2010) Drainage-independent genetic structure and high genetic diversity of endangered freshwater pearl mussels (Margaritifera margaritifera) in northern Europe. Conservation Genetics, 11, 13391350.

Gosselin M.-P. (2015) Conservation of the freshwater pearl mussel (Margaritifera margaritifera) in the river Rede, UK: identification of instream indicators for catchment-scale issues. Limnologica, 50, 58-66.

Greischar M.A. \& Koskella B. (2007) A synthesis of experimental work on parasite local adaptation. Ecology Letters, 10, 418-434.

Gum B., Lange M. \& Geist J. (2011) A critical reflection on the success of rearing and culturing juvenile freshwater mussels with a focus on the endangered freshwater pearl mussel (Margaritifera margaritifera L.). Aquatic Conservation: Marine and Freshwater Ecosystems, 21, 743-751.

Hastie L.C. \& Boon P.J. (2001) Does electrofishing harm freshwater pearl mussels? Aquatic Conservation: Marine and Freshwater Ecosystems, 11, 149-152.

Hastie L. \& Cosgrove P. (2001) The decline of migratory salmonid stocks: a new threat to pearl mussels in Scotland. Freshwater Forum, 15, 85-96.

Hastie L.C. \& Young M.R. (2001) Freshwater pearl mussel (Margaritifera margaritifera) glochidiosis in wild and farmed salmonid stocks in Scotland. Hydrobiologia, 445, 109-119.

Helama S. \& Valovirta I. (2007) Shell morphometry, pre-mortal taphonomy and ontogeny-related growth characteristics of freshwater pearl mussel in northern Finland. Annales Zoologici Fennici, 44, 285-302. 
Hiltunen M. (2010) Kalatutkimusraportti 4, Pohjolan voima: Iijoen jokialueen kalatalousvelvoitteen tarkkailutulokset vuosina 2005-2009. Muhoksen kalatalouspalvelut. [in Finnish].

Howard J.K. \& Cuffey K.M. (2006) The functional role of native freshwater mussels in the fluvial benthic environment. Freshwater Biology, 51, 460-474.

Ieshko E.P., Geist J., Murzina S.A., Veselov A.E., Lebedeva D.I. \& Zioganov V.V. (2016) The characteristics of the infection of juvenile Atlantic salmon with glochidia of the freshwater pearl mussel in rivers of Northwest Russia. Knowledge and Management of Aquatic Ecosystems, 417, DOI: 10.1051/kmae/2015039.

Ieshko E.P., Larson B.M., Pavlov U.L., Barskaya U.U., Lebedeva D.I. \& Novohatskaya O.V. (2009) Population dynamics of glochidia of the freshwater pearl mussel Margaritifera margaritifera L., parasitizing on juvenile Salmonidae fishes in northern water reservoirs. Biology Bulletin, 36, 624-629.

Johansen M., Elliott J.M. \& Klemetsen A. (2005) A comparative study of juvenile salmon density in 20 streams throughout a very large river system in northern Norway. Ecology of Freshwater Fish, 14, 96-110.

Kallio-Nyberg I., Jutila E., Koljonen M.-L., Koskiniemi J. \& Saloniemi I. (2010) Can the lost migratory Salmo trutta stocks be compensated with resident trout stocks in coastal rivers? Fisheries Research, 102, 69-79.

Karlsson S., Larsen B.M. \& Hindar K. (2014) Host-dependent genetic variation in freshwater pearl mussel (Margaritifera margaritifera L.). Hydrobiologia, 735, 179-190. Karppinen P., Mäkinen T.S., Erkinaro J., Kostin V.V., Sadkovskij R.V., Lupandin A.I. et al. (2002) Migratory and route-seeking behaviour of ascending Atlantic salmon in the regulated River Tuloma. Hydrobiologia, 483, 23-30.

Klemetsen A., Amundsen P.-A., Dempson J.B., Jonsson B., Jonsson N., O’Connell M.F. et al. (2003) Atlantic salmon Salmo salar L., brown trout Salmo trutta L. and Arctic charr Salvelinus alpinus (L.): a review of aspects of their life histories. Ecology of Freshwater Fish, 12, 1-59.

Knouft J.H. \& Spotila J.R. (2002) Assessment of movements of resident stream brown trout, Salmo trutta L., among contiguous sections of stream. Ecology of Freshwater Fish, 11, 85-92. 
Lopes-Lima M., Sousa R., Geist J., Aldridge D.C., Araujo R., Bergengren J. et al. (2016) Conservation status of freshwater mussels in Europe: state of the art and future challenges. Biological Reviews, DOI: 10.1111/brv.12244.

Luhta P.-L. \& Moilanen E. (2006) Metsähallituksen luonnonsuojelujulkaisuja. Sarja B77: Iijoen kunnostettujen jokien kalataloudellinen seuranta 2000-2004. Metsähallitus, Helsinki. [in Finnish].

Marttila M., Orell P., Erkinaro J., Romakkaniemi A., Huusko A. \& Jokikokko E. et al. (2014) RKTL:n työraportteja 6/2014: Rakennettujen jokien kalataloudella aiheutuneet vahingot ja kalatalousvelvoitteet. Riista- ja kalatalouden tutkimuslaitos, Helsinki. [in Finnish].

Orell P., Jaukkuri M., Kanniainen T., van der Meer O., Mäki-Petäys A., Huusko R. et al. (2011) Vaelluskalat palaavat Iijokeen. Ylisiirrettyjen lohien radiotelemetriaseuranta Iijoella v. 2009-2010. Työraportti 28.1.2011. Riistan- ja kalantutkimus. [in Finnish]. Österling E.M. (2015) Influence of host fish age on a mussel parasite differs among rivers: implications for conservation. Limnologica, 50, 75-79.

Österling E.M. \& Wengström N. (2015) Test of the host fish species of a unionoid mussel: a comparison between natural and artificial encystment. Limnologica, 50, 8083.

Österling M.E. \& Larsen B.M. (2013) Impact of origin and condition of host fish (Salmo trutta) on parasitic larvae of Margaritifera margaritifera. Aquatic Conservation: Marine and Freshwater Ecosystems, 23, 564-570.

Oulasvirta P. (2011) Distribution and status of the freshwater pearl mussel Margaritifera margaritifera in northern Fennoscandia. Toxicological \& Environmental Chemistry, 93, 1713-1730.

Paine R.T. (1995) A conversation on refining the concept of keystone species. Conservation Biology, 9, 962-964.

Parrish D.L., Behnke R.J., Gephard S.R., McCormick S.D. \& Reeves G.H. (1998) Why aren't there more Atlantic salmon (Salmo salar)? Canadian Journal of Fisheries and Aquatic Sciences, 55 (S1), 281-287.

Pimm S.L., Russell G.J., Gittleman J.L. \& Brooks T.M. (1995) The future of biodiversity. Science, 269, 347-350. 
Poulin R. (2007) Evolutionary Ecology of Parasites. Princeton University Press, New Jersey.

Sala O.E., Chapin III F.S., Armesto J.J., Berlow E., Bloomfield J., Dirzo R. et al. (2000) Global biodiversity scenarios for the year 2100. Science, 287, 1770-1774.

Salonen J.K. \& Taskinen J. (2017) Electrofishing as a new method to search for unknown populations of the endangered freshwater pearl mussel Margaritifera margaritifera. Aquatic Conservation: Marine and Freshwater Ecosystems, 27, 115127.

Salonen J.K., Marjomäki T.J. \& Taskinen J. (2016) An alien fish threatens an endangered parasitic bivalve: the relationship between brook trout (Salvelinus fontinalis) and freshwater pearl mussel (Margaritifera margaritifera) in northern Europe. Aquatic Conservation: Marine and Freshwater Ecosystems, 26, 1130-1144. Strahler A.N. (1952) Hypsometric (area-altitude) analysis of erosional topography. Bulletin of the Geological Society of America, 63, 1117-1142.

Taeubert J.-E., Denic M., Gum B., Lange M. \& Geist J. (2010) Suitability of different salmonid strains as hosts for the endangered freshwater pearl mussel (Margaritifera margaritifera L.). Aquatic Conservation: Marine and Freshwater Ecosystems, 20, 728734.

Thomas C.D., Cameron A., Green R.E., Bakkenes M., Beaumont L.J., Collingham Y.C. et al. (2004) Extinction risk from climate change. Nature, 427, 145-148.

Thompson J.N. (1994) The coevolutionary process. The University of Chicago Press, Illinois.

Thompson J.N. (2005) The Geographic mosaic of coevolution, The University of Chicago Press, Illinois.

Valovirta I. (1990) Livojoen ja Loukusanjoen entisöintialueiden jokihelmisimpukkakannat ja niiden suojelu. Raakkuraportti 5. Helsingin yliopisto, luonnontieteellinen keskusmuseo, eläinmuseo, Helsinki. [in Finnish].

Valovirta I. (1993) Livojoen alajuoksun entisöintialueiden jokihelmisimpukkakannan inventointi ja suojelutoimet v. 1992. Helsingin yliopiston eläinmuseo, Helsinki. [in Finnish].

Vaughn C.C., Nichols S.J. \& Spooner D.E. (2008) Community and foodweb ecology of freshwater mussels. Journal of the North American Benthological Society, 27, 409-423. 
Young M. \& Williams J. (1984) The reproductive biology of the freshwater pearl mussel Margaritifera margaritifera (LINN.) in Scotland I. Field studies. Archiv für Hydrobiologie, 99, 405-422.

Young M.R., Cosgrove P.J. \& Hastie L.C. (2001) The extent of, and causes for, the decline of a highly threatened naiad: Margaritifera margaritifera. In: Ecology and evolution of the freshwater mussels Unionoida (Eds G. Bauer \& K Wächtler), pp. 337357. Springer, Berlin. 


\section{Tables}

Table 1. The fish species and strains used in the cage experiments, with number of replicate cages $\left(\mathrm{N}_{\mathrm{r}}\right)$ and total number of fish in the cages $\left(\mathrm{N}_{\mathrm{f}}\right)$ in each river at the beginning of the experiments. In 2011 the age of the fish varied from 0+ to 1+, while in 2012-2013 all the fish were 0+. The first row indicates the time periods of the caging in the rivers, of which Livojoki and Simojoki are large salmon rivers while the others probably have been inhabited only by brown trout. $\mathrm{W}=$ wild fish.

\begin{tabular}{|c|c|c|c|c|c|c|c|c|c|c|c|c|c|c|c|c|c|c|}
\hline \multirow[b]{3}{*}{ Species (strain) } & \multicolumn{8}{|c|}{05 Sep -11 Oct 2011} & \multicolumn{6}{|c|}{27 Aug -18 Oct 2012} & \multicolumn{4}{|c|}{20 Aug -16 Oct 2013} \\
\hline & \multicolumn{2}{|c|}{ Koivuoja } & \multicolumn{2}{|c|}{ Lohijoki } & \multicolumn{2}{|c|}{ Portinjoki } & \multicolumn{2}{|c|}{ Livojoki } & \multicolumn{2}{|c|}{ Ala-H. } & \multicolumn{2}{|c|}{ Porrasl. } & \multicolumn{2}{|c|}{ Livojoki } & \multicolumn{2}{|c|}{ Livojoki } & \multicolumn{2}{|c|}{ Simojoki } \\
\hline & $\mathrm{N}_{\mathrm{r}}$ & $\mathrm{N}_{\mathrm{f}}$ & $\mathrm{N}_{\mathrm{r}}$ & $\mathrm{N}_{\mathrm{f}}$ & $\mathrm{N}_{\mathrm{r}}$ & $\mathrm{N}_{\mathrm{f}}$ & $\mathrm{N}_{\mathrm{r}}$ & $\mathrm{N}_{\mathrm{f}}$ & $\mathrm{N}_{\mathrm{r}}$ & $\mathrm{N}_{\mathrm{f}}$ & $\mathrm{N}_{\mathrm{r}}$ & $\mathrm{N}_{\mathrm{f}}$ & $\mathrm{N}_{\mathrm{r}}$ & $\mathrm{N}_{\mathrm{f}}$ & $\mathrm{N}_{\mathrm{r}}$ & $\mathrm{N}_{\mathrm{f}}$ & $\mathrm{N}_{\mathrm{r}}$ & $\mathrm{N}_{\mathrm{f}}$ \\
\hline Atlantic salmon (Iijoki) & 2 & 53 & 2 & 50 & 2 & 51 & 2 & 41 & 4 & 60 & 4 & 65 & 4 & 66 & 3 & 96 & 3 & 92 \\
\hline Atlantic salmon (Simojoki), W & & & & & & & & & & & & & & & 3 & 76 & 2 & 36 \\
\hline Atlantic salmon (Tornionjoki) & & & & & & & & & & & & & & & 3 & 96 & 3 & 91 \\
\hline Brown trout (Iijoki) & 3 & 78 & 3 & 75 & 3 & 77 & 3 & 68 & 4 & 60 & 4 & 63 & 4 & 62 & 3 & 98 & 3 & 97 \\
\hline Brown trout (Rautalampi) & & & & & & & 2 & 40 & 2 & 61 & 2 & 64 & 2 & 64 & & & & \\
\hline Brown trout (Kitkajoki) & & & & & & & 2 & 42 & & & & & 2 & 65 & & & & \\
\hline Brown trout (Lohijoki), W & & & 2 & 43 & 2 & 43 & & & & & & & & & & & & \\
\hline Brown trout (Portinjoki), W & & & 2 & 48 & 2 & 47 & & & & & & & & & & & & \\
\hline Brown trout (Ala-Haapuanoja), W & & & & & & & & & 2 & 55 & & & & & & & & \\
\hline Brown trout (Porraslammenoja), W & & & & & & & & & & & 1 & 3 & & & & & & \\
\hline
\end{tabular}


Table 2. Tank-specific lists of the fish species and strains with their age and number $(\mathrm{N})$ at the beginning of the laboratory experiments. The first row indicates the time periods of the experiments from the exposure to M. margaritifera (FPM) glochidia to the last fish examined, and the origins of FPM in the experiments. In each year, glochidia were collected a day before the beginning of the experiment. Koivuoja and Jukuanoja have likely been inhabited only by brown trout, while Luttojoki is a large salmon river. All the fish were farmed and had no previous contact to FPM.

\begin{tabular}{|c|c|c|c|c|c|c|c|c|c|c|c|}
\hline \multicolumn{4}{|c|}{08 Sep 2011 - 09 May 2012 (Koivuoja FPM) } & \multicolumn{4}{|c|}{28 Aug 2012 - 11 Mar 2013 (Jukuanoja FPM) } & \multicolumn{4}{|c|}{28 Aug 2013 - 27 Nov 2013 (Luttojoki FPM) } \\
\hline Tank & Species (strain) & Age & $\mathrm{N}$ & Tank & Species (strain) & Age & $\mathrm{N}$ & Tank & Species (strain) & Age & $\mathrm{N}$ \\
\hline 1 & Atlantic salmon (Iijoki) & $0+$ & 60 & 1 & Atlantic salmon (Iijoki) & $0+$ & 50 & 1 & Atlantic salmon (Iijoki) & $1+$ & 13 \\
\hline 2 & Atlantic salmon (Iijoki) & $0+$ & 60 & 1 & Brown trout (Iijoki) & $0+$ & 50 & 2 & Atlantic salmon (Iijoki) & $1+$ & 13 \\
\hline 3 & Brown trout (Iijoki) & $0+$ & 100 & 2 & Atlantic salmon (Iijoki) & $0+$ & 50 & 3 & Brown trout (Iijoki/Rautalampi) & $0+$ & 100 \\
\hline \multirow[t]{3}{*}{4} & Brown trout (Iijoki) & $0+$ & 100 & 2 & Brown trout (Iijoki) & $0+$ & 50 & 4 & Brown trout (Iijoki/Rautalampi) & $0+$ & 100 \\
\hline & & & & & & & & 5 & Brown trout (Iijoki/Rautalampi) & $0+$ & 100 \\
\hline & & & & & & & & 6 & Brown trout (Iijoki/Rautalampi) & $0+$ & 100 \\
\hline
\end{tabular}


Table 3. The $p$-values of statistical tests between brown trout and salmon in prevalence (percentage of infected fish), abundance (number of glochidia per fish) and length of glochidia when FPM originated from (a) small brown trout streams and (b) large salmon rivers. The symbols * and $(*)$ indicate the significant differences at < $5 \%$ and at $<10 \%$ risk level, respectively.

a)

\begin{tabular}{lllccc}
\hline Origin of FPM & Suitable host & Less (or equally) suitable host & $p_{\text {prevalence }}$ & $p_{\text {abundance }}$ & $p_{\text {glochidia length }}$ \\
\hline Lohijoki & Brown trout (Iijoki) & Atlantic salmon (Iijoki) & 1 & $>0.999$ & - \\
& Brown trout (Lohijoki) & Atlantic salmon (Iijoki) & 1 & $>0.999$ & - \\
& Brown trout (Portinjoki) & Atlantic salmon (Iijoki) & 1 & 0.986 & - \\
Portinjoki & Brown trout (Iijoki) & Atlantic salmon (Iijoki) & 1 & $0.018 *$ & - \\
& Brown trout (Portinjoki) & Atlantic salmon (Iijoki) & 1 & $>0.999$ & - \\
& Brown trout (Lohijoki) & Atlantic salmon (Iijoki) & 1 & $0.003 *$ & - \\
Ala-Haapuanoja & Brown trout (Iijoki) & Atlantic salmon (Iijoki) & 0.849 & $<0.001 *$ & $>0.999$ \\
& Brown trout (Ala-Haapuanoja) & Atlantic salmon (Iijoki) & 0.708 & $<0.001 *$ & 0.540 \\
& Brown trout (Rautalampi) & Atlantic salmon (Iijoki) & 0.654 & $<0.001 *$ & 0.501 \\
Porraslammenoja & Brown trout (Iijoki) & Atlantic salmon (Iijoki) & $<0.001 *$ & $<0.001 *$ & 0.351 \\
& Brown trout (Porraslammenoja) & Atlantic salmon (Iijoki) & 0.489 & $0.054(*)$ & $>0.999$ \\
Jukuanoja (time point 1) & Brown trout (Rautalampi) & Atlantic salmon (Iijoki) & $<0.001 *$ & $<0.001 *$ & $0.051(*)$ \\
Jukuanoja (time point 2) & Brown trout (Iijoki) & Atlantic salmon (Iijoki) & $<0.001 *$ & $<0.001 *$ & 0.110 \\
Jukuanoja (time point 3) & Brown trout (Iijoki) & Atlantic salmon (Iijoki) & $0.001 *$ & $<0.001 *$ & $<0.001 *$ \\
Jukuanoja (time point 4) & Brown trout (Iijoki) & Atlantic salmon (Iijoki) & $0.015 *$ & $0.015 *$ & - \\
Koivuoja (field experiment) & Brown trout (Iijoki) & Atlantic salmon (Iijoki) & Atlantic salmon (Iijoki) & $<0.001 *$ & $<0.001 *$ \\
Koivuoja (lab experiment) & Atlantic salmon (Iijoki) & Brown trout (Iijoki) & 0.550 & $0.091(*)$ & - \\
\hline
\end{tabular}


b)

\begin{tabular}{lllllc}
\hline Origin of FPM & Suitable host & Less or equally suitable host & $p_{\text {Prevalence }}$ & $p_{\text {Abundance }}$ & $p_{\text {Glochidia length }}$ \\
\hline Livojoki (2011) & Atlantic salmon (Iijoki) & Brown trout (Iijoki) & $<0.001 *$ & $<0.001 *$ & - \\
& Atlantic salmon (Iijoki) & Brown trout (Kitkajoki) & $<0.001 *$ & $<0.001 *$ & - \\
& Atlantic salmon (Iijoki) & Brown trout (Rautalampi) & $<0.001 *$ & 0.129 & - \\
Livojoki (2012) & Atlantic salmon (Iijoki) & Brown trout (Iijoki) & $<0.001 *$ & $<0.001 *$ & $>0.999$ \\
& Atlantic salmon (Iijoki) & Brown trout (Kitkajoki) & $<0.001 *$ & $0.006 *$ & $0.048 *$ \\
& Atlantic salmon (Iijoki) & Brown trout (Rautalampi) & 0.168 & 0.348 & 0.129 \\
Livojoki (2013) & Atlantic salmon (Iijoki) & Brown trout (Iijoki) & $<0.001 *$ & $<0.001 *$ & $<0.001 *$ \\
& Atlantic salmon (Simojoki) & Brown trout (Iijoki) & $<0.001 *$ & $<0.001 *$ & $<0.001 *$ \\
& Atlantic salmon (Tornionjoki) & Brown trout (Iijoki) & $<0.001 *<0.001 *$ & $<0.001 *$ \\
Simojoki & Atlantic salmon (Iijoki) & Brown trout (Iijoki) & $<0.001 *$ & $<0.001 *$ & $>0.999$ \\
& Atlantic salmon (Simojoki) & Brown trout (Iijoki) & $<0.001 *$ & $0.003 *$ & 0.510 \\
& Atlantic salmon (Tornionjoki) & Brown trout (Iijoki) & $<0.001 *$ & $<0.001 *$ & 0.480 \\
Luttojoki & Atlantic salmon (Iijoki) & Brown trout (Iijoki) & $<0.001 *$ & $<0.001 *$ & $<0.001 *$ \\
\hline
\end{tabular}


Table 4. Mean length (longest diameter of round or slightly oval larva) \pm S.E. ( $\mu \mathrm{m}$ ) of encysted M. margaritifera glochidia in fish in the cage experiments of 20122013. The first row indicates the time period when the hosts were caged in the rivers, of which Livojoki and Simojoki are large salmon rivers, while Ala-Haapuanoja and Porraslammenoja have probably been inhabited only by brown trout. The symbols * and (*) indicate significant differences between salmon and brown trout at < $5 \%$ and at $<10 \%$ risk level, respectively. $\mathrm{W}=$ wild fish.

\begin{tabular}{lcccccc}
\hline & \multicolumn{3}{c}{ 27 Aug -18 Nov 2012 } & & \multicolumn{2}{c}{ 20 Aug -16 Nov 2013 } \\
\cline { 2 - 4 } \cline { 5 - 7 } Species (strain) & Ala-Haapuanoja & Porraslammenoja & Livojoki & & Livojoki & Simojoki \\
\hline Atlantic salmon (Iijoki) & $83 \pm 2.2$ & $112 \pm 2.7(*)$ & $110 \pm 1.6 *$ & & $113 \pm 1.1 *$ & $91 \pm 1.8$ \\
Atlantic salmon (Simojoki), W & & & & & $117 \pm 1.6 *$ & $100 \pm 3.0$ \\
Atlantic salmon (Tornionjoki) & & & & $110 \pm 1.2 *$ & $98 \pm 2.0$ \\
Brown trout (Iijoki) & $82 \pm 1.3$ & $119 \pm 4.5$ & $110 \pm 4.3$ & & $97 \pm 2.6 *$ & $94 \pm 4.2$ \\
Brown trout (Rautalampi) & $79 \pm 2.0$ & $121 \pm 2.6(*)$ & $105 \pm 1.9$ & & \\
Brown trout (Kitkajoki) & & & $90 \pm 6.4 *$ & & \\
Brown trout (Ala-Haapuanoja), W & $80 \pm 0.9$ & & & & & \\
Brown trout (Porraslammenoja), W & & $119 \pm 4.5$ & & & \\
\hline
\end{tabular}

Table 5. Mean length (longest diameter of round or slightly oval larva) \pm S.E. ( $\mu$ m) of encysted M. margaritifera (FPM) glochidia in fish (Iijoki strain) in the laboratory experiments of 2012-2013. In the first experiment fish were exposed to Jukuanoja (a brown trout stream) FPM on August 28, 2012, and were examined in four time points, while in the second experiment fish were exposed to Luttojoki (a salmon river) FPM on August 28, 2013, and all were examined at the same time on November 27. The symbol $*$ indicate significant difference between salmon and brown trout at $<5 \%$ risk level.

\begin{tabular}{lcccccc}
\hline & \multicolumn{4}{c}{$2012-2013$} & & 2013 \\
\cline { 2 - 4 } Species & 11 Sep 2012 & 19 Sep 2012 & 03 Dec 2012 & 11 Mar 2013 & & 27 Nov 2013 \\
\hline Atlantic salmon & $93 \pm 4.7$ & $91 \pm 4.5 *$ & - & - & & $274 \pm 7.2 *$ \\
Brown trout & $99 \pm 1.5$ & $132 \pm 2.8 *$ & $245 \pm 10$ & $279 \pm 11$ & & $183 \pm 5.0 *$ \\
\hline
\end{tabular}




\section{Figure legends}

Figure 1. Maps of Europe, Northern Finland with the large salmon rivers (Luttojoki, Simojoki, Livojoki) studied, and the River Iijoki catchment with the two-letter codes representing the rough locations of the small brown trout tributaries Jukuanoja (Jo), Portinjoki (Pj), Porraslammenoja (Po), Koivuoja (Ko), Ala-Haapuanoja (Ao) and Lohijoki (Lj). The River Luttojoki belongs to the River Tuloma catchment, located mostly on the other side of the Russian border. At present, only the River Simojoki is free-flowing, while the other study rivers/catchments are dammed. FPM recruitment has declined at least in the River Luttojoki (Oulasvirta, 2011) and in the River Livojoki (Valovirta, 1990, 1993).

Figure 2. The number of $M$. margaritifera (FPM) glochidia per fish (abundance) and percentage of infected fish (prevalence) caged in brown trout streams Lohijoki (a), Portinjoki (b), Ala-Haapuanoja (c), and Porraslammenoja (d). The box-and-whisker plot depicts median with $25 \%$ and $75 \%$ quartiles and with minimum and maximum, and with mean as the individual diamond. The symbols * and (*) indicate significant differences in comparison with salmon at $<5 \%$ and at $<10 \%$ risk level, respectively. $\mathrm{N}$ is the number of fish examined.

Figure 3. The number of M. margaritifera (FPM) glochidia per fish (abundance) and percentage of infected fish (prevalence) of Iijoki strains exposed to brown trout stream Jukuanoja FPM in laboratory tanks on 28 August 2012. The box-and-whisker plot depicts median with $25 \%$ and $75 \%$ quartiles and with minimum and maximum, and with mean as the individual diamond. The symbol * indicates significant difference in comparison with salmon at $<5 \%$ risk level. $\mathrm{N}$ is the number of fish examined.

Figure 4. The number of M. margaritifera (FPM) glochidia per fish (abundance) and percentage of infected fish (prevalence) of Iijoki strains exposed to brown trout stream Koivuoja FPM a) in the cage experiment, and b) in the laboratory experiment. The boxand-whisker plot depicts median with $25 \%$ and $75 \%$ quartiles and with minimum and maximum, and with mean as the individual diamond. The symbols * and (*) indicate 
significant differences in comparison with salmon at $<5 \%$ and at $<10 \%$ risk level, respectively. $\mathrm{N}$ is the number of fish examined.

Figure 5. The number of M. margaritifera (FPM) glochidia per fish (abundance) and percentage of infected fish (prevalence) caged in salmon rivers Livojoki in 2011 (a), 2012 (b), and 2013 (c), and Simojoki in 2013 (d). The box-and-whisker plot depicts median with $25 \%$ and $75 \%$ quartiles and with minimum and maximum, and with mean as the individual diamond. The symbol * indicates significant difference in comparison with salmon $(\mathrm{a}, \mathrm{b})$, and in comparison with brown trout $(\mathrm{c}, \mathrm{d})$ at $<5 \%$ risk level. $\mathrm{N}$ is the number of fish examined.

Figure 6. The fish weight standardized number of $M$. margaritifera (FPM) glochidia per fish (abundance) and percentage of infected fish (prevalence) of Iijoki strains exposed to FPM from the salmon river Luttojoki. The box-and-whisker plot depicts median with $25 \%$ and $75 \%$ quartiles and with minimum and maximum, and with mean as the individual diamond. The symbol $*$ indicates significant difference in comparison with brown trout at $<5 \%$ risk level. $\mathrm{N}$ is the number of fish examined.

\section{Supporting Information}

Table S1. The physical characteristics of the study rivers and streams.

Table S2. Mean total lengths of each fish group in the experiments. 


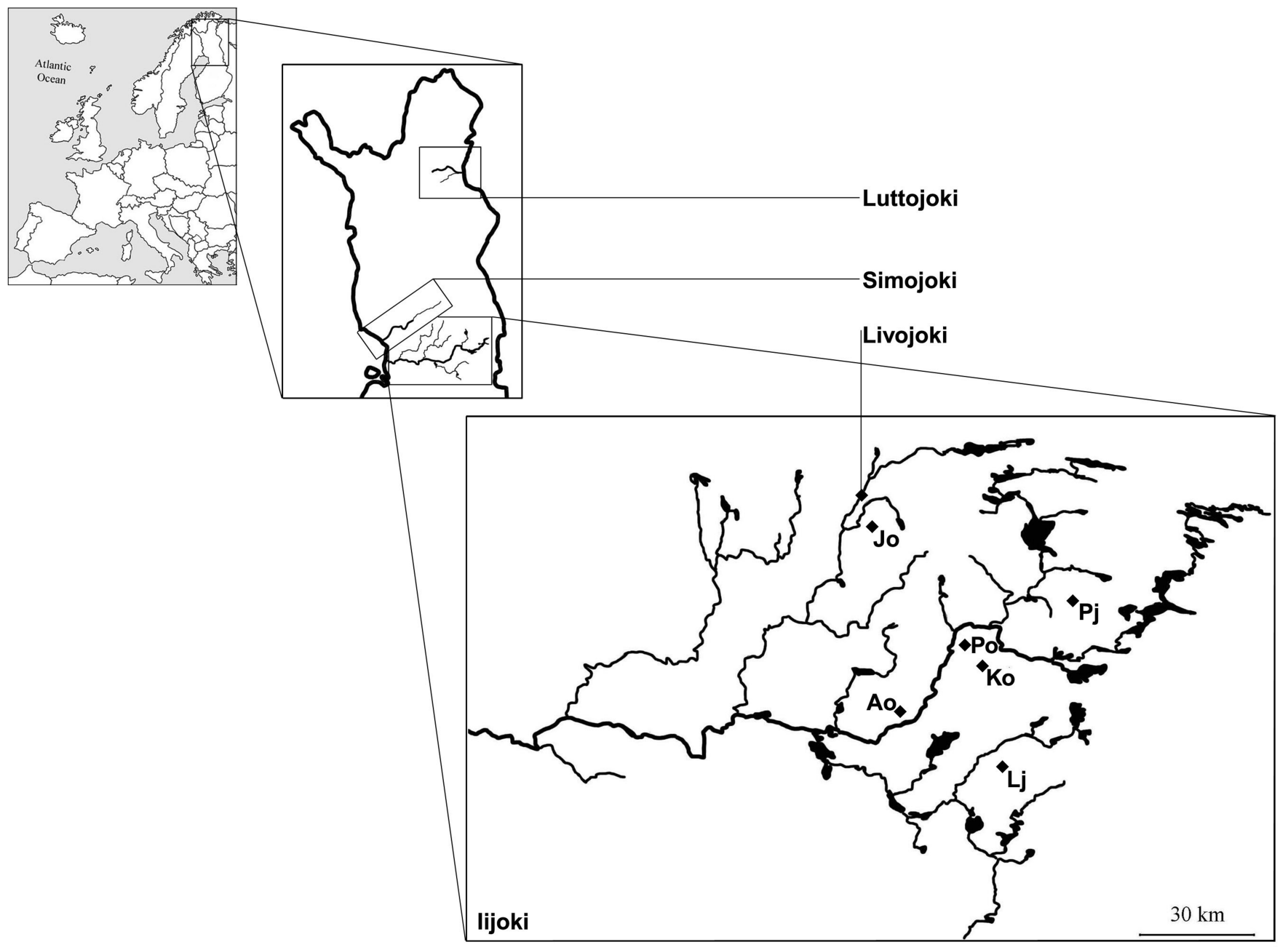



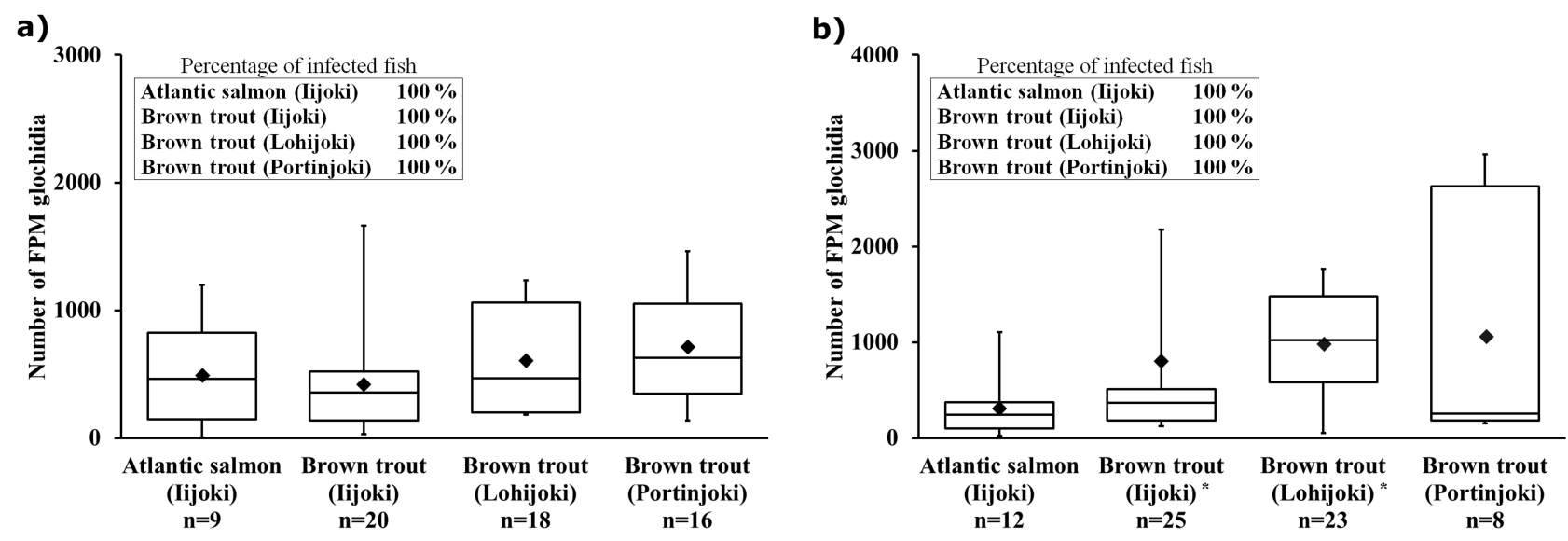

c

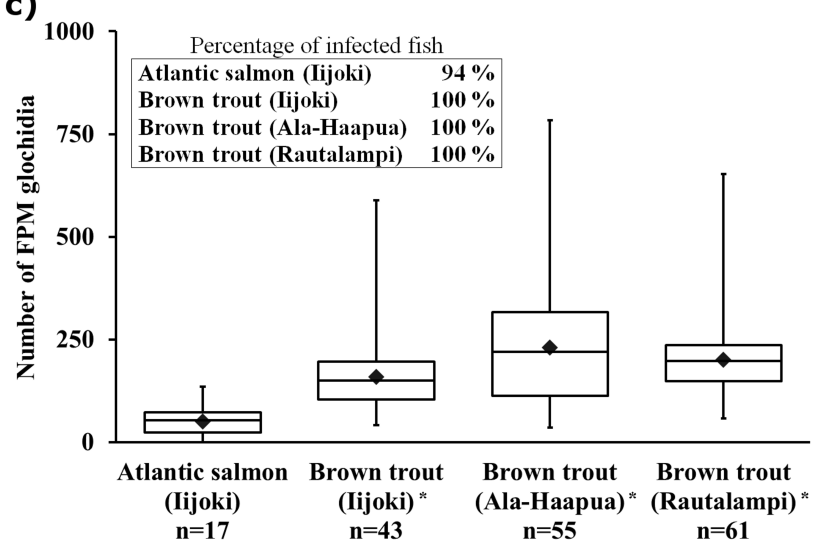

d)

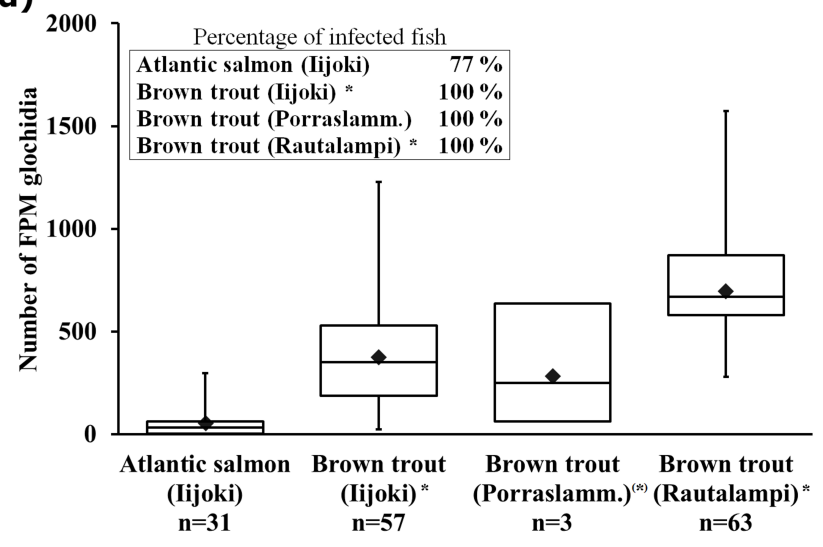




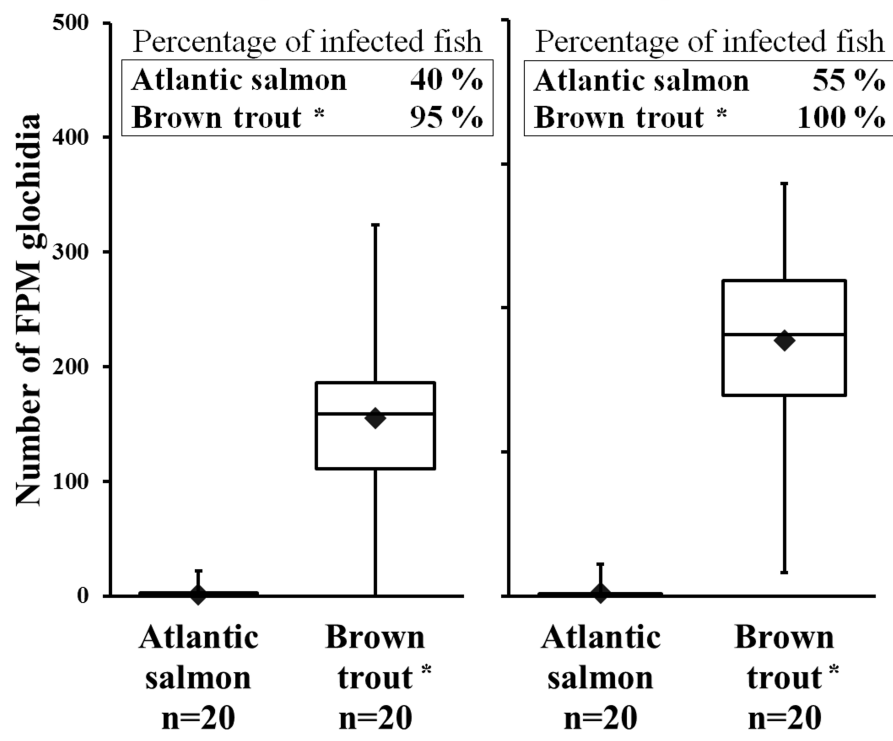

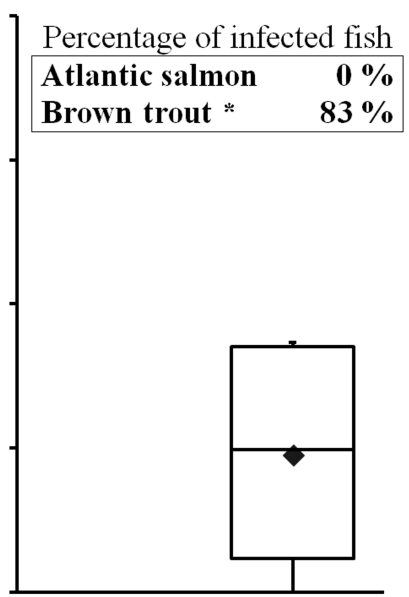

Atlantic

Brown salmon trout * $n=6$

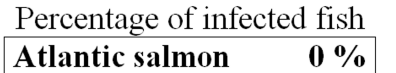

Brown trout * $\quad 90 \%$


a)

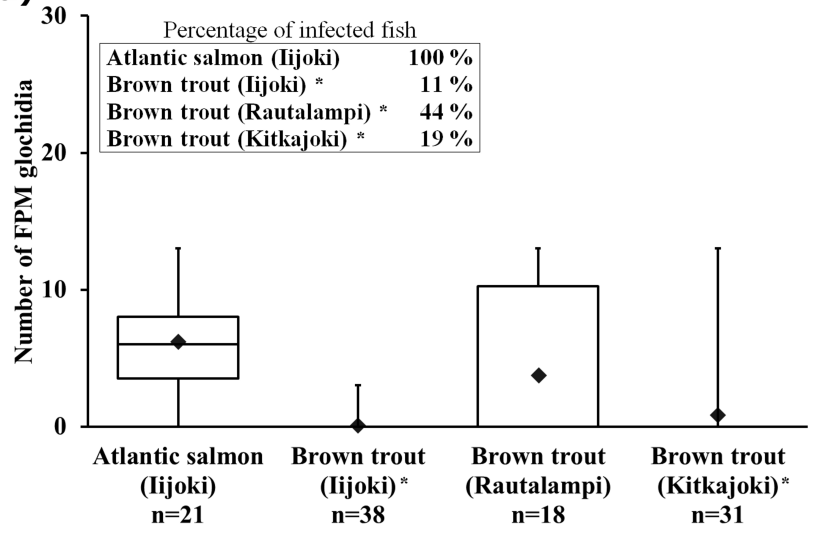

c)

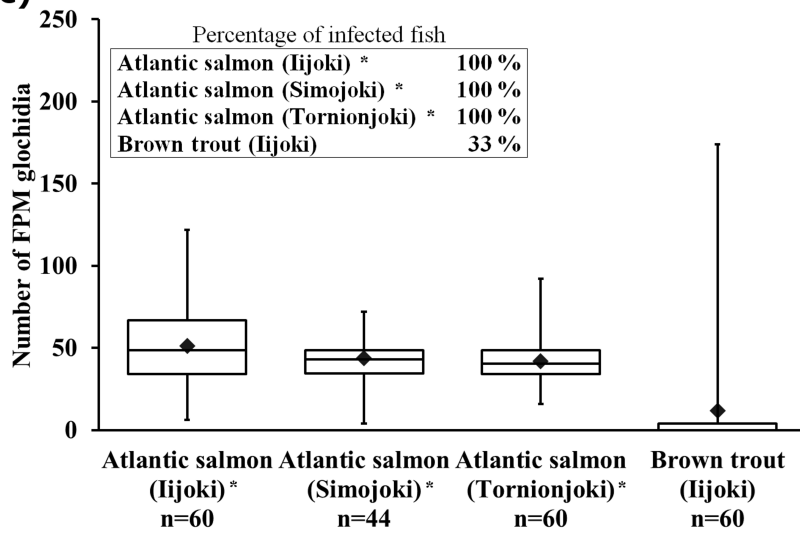

b)

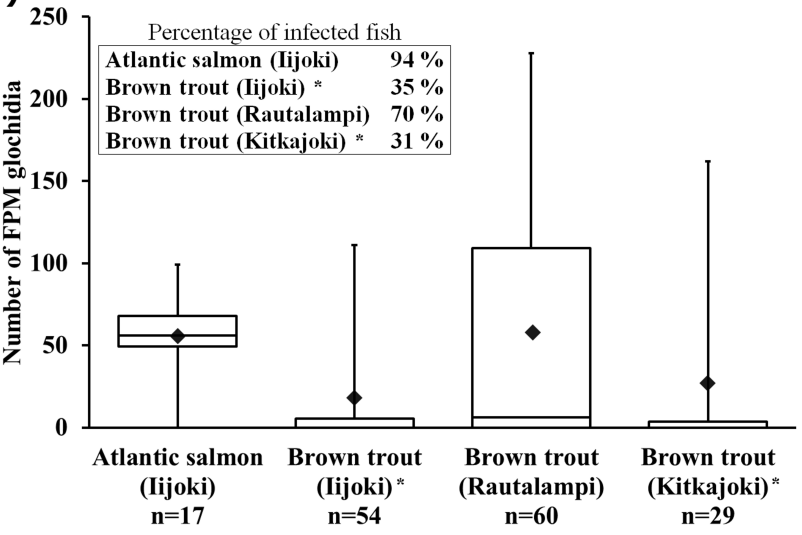

d)

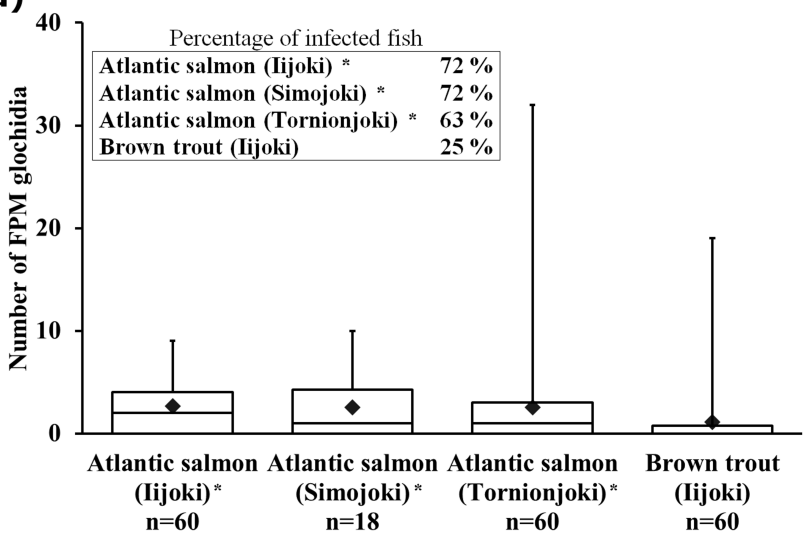




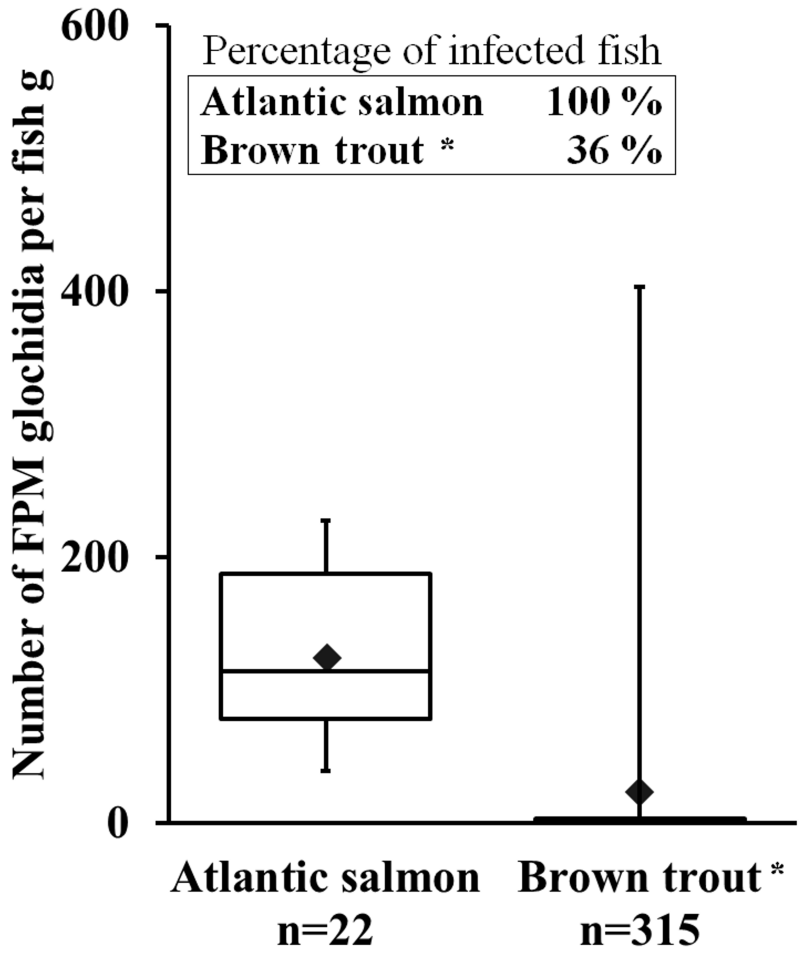

